\title{
VARIABILITY OF HOST DAMAGE AND RESPONSE OF SOME COWPEA BREEDING LINES TO ROOT-KNOT NEMATODES, Meloidogyne spp.
}

\author{
Tijjani, $\mathrm{I}^{1+}$ and Atungwu, J.J. ${ }^{2}$ \\ ${ }^{1}$ Department of Crop protection, Faculty of Agriculture Bayero University, P.M.B. 3011,Kano. Nigeria. \\ ${ }^{2}$ Department of Crop Protection, Federal University of Agriculture, P.M.B 2240, Abeokuta, Nigeria. \\ ${ }^{+}$Corresponding author :+2348067062748; ibrahimtijiani99@yahoo.com
}

\begin{abstract}
Field and screen house studies were conducted at the International Institute of Tropical Agriculture (IITA) Research Farms, Minjibir, Kano State and farmer's plot, Ringim, Jigawa State in Sudan Savannah Agro-ecological Zone, North-Western, Nigeria to investigate the reaction of ten cowpea breeding lines to infestation of Meloidogyne spp. Seven-day old seedlings were inoculated with 0 or 5000 eggs of Meloidogyne spp. The experiment was a 2 x 10 factorial, fitted into Randomized Complete Block Design laid out in the fields while the screen house trial laid in Completely Randomized Design. In each location, treatments were replicated four times. Data were collected on plant height, stem girth, root galls, number of days $50 \%$ to flowering, pods/plant and seeds/pod. Data obtained were subjected to Analysis of Variance. Statistically variable treatment means were separated using standard error of means at $5 \%$ level of probability. Results showed that Meloidogyne spp. induced stunting which results in poor growth and in severe cases affects the time of maturity on susceptible cowpea plants. Hence, highly nematode infested soil should be treated before sowing in order to ensure high qualitative harvest.
\end{abstract}

Key words: Cowpea, Meloidogyne spp., plant height, stem girth.

\section{INTRODUCTION}

Cowpea $\{$ Vigna unguiculata (L.) Walp $\}$ is a food and fodder legume of significant economic importance worldwide, especially in semi-arid regions of Africa. Cowpea was cultivated in an estimated area of 12.52 million hectares with an annual production of 5.59 million tonnes of dry grains worldwide (FAOSTAT, 2014). Nigeria, with grain production estimated at 2.14 metric tonnes on 3.7 million ha (FAOSTAT, 2014), reviewed the largest producer of cowpea in the world.

Cowpea is an important grain legume in the savannas of West Africa providing a relatively cheap source of vegetable protein to the urban and rural poor, as well as mineral and protein rich fodder for livestock feeding and cash to the farmers. Cowpea is an essential component of cropping systems in the drier regions of the tropics and subtropics (Singh et al., 2003) and is important to the livelihood of millions of people (Quin, 1997). As a legume, cowpea can contribute to soil fertility, mainly through its nitrogen fixing abilities. Its residue is an important fodder resource for ruminant livestock (Tarawaliet al., 1997) and provides an inexpensive and nutritious food for human consumption (Quin, 1997).

Plant-parasitic nematodes are microscopic worms that live in the soil and feed on the roots of plants or in other plant parts such as tubers, leaves, buds, flowers or seeds. Nematode damage limited the root system, which leads to reduced rate of uptake of nutrients and water (Anwar and Din, 1986). Impaired water relations appear to contribute substantially to reduced rates of top growth. This is probably because the developing giant cell systems and disruption of the developing xylem, which interferes with translocation of food and water to foliage (Davis et al., 2003;
Anwar and Van Gundy, 1993). Symptoms of infection are presence of root galls, excessive branching of roots, and reduced root systems. Poor germination, death of seedlings and yield loss may be observed in cases of heavy infestations (Mishra, 1992).

Root-knot nematode, Meloidogyne spp. was first observed in Nigeria on cowpea in 1958 and documented in 1960 (Anon., 1961). Olowe (2009) reported a yield reduction of 10 to $65 \%$, similarly, a cowpea grain yield loss of $69 \%$ caused by root-knot nematode was also reported by Babatola and Omotade (1991).The aim of this research is to study the host responses of ten cowpea breeding lines infestation with root-knot nematode.

\section{MATERIALS AND METHODS}

Experimental Design Set up: The experiments were conducted in the fields and screenhouse during the 2012 dry season cropping period. Field experiments were conducted at the IITA Research Farms, Minjibir, Kano State and farmer's plot at Ringim, Jigawa State and later evaluated in the screenhouse. On the field, a $10 \times 2$ factorial experiment, fitted into randomized complete block design with four replications was laid out. Twenty treatments were replicated four times making 80 plots in each location. Each plot was $1.2 \mathrm{~m} \times 1.8 \mathrm{~m}$ (2.16 $\mathrm{m}^{2}$ ) with space of $0.5 \mathrm{~m}$ between the plots in a column and $1.0 \mathrm{~m}$ between the rows.

The screenhouse experiment was carried out in the screenhouse at IITA Kano station (Latitude $11^{\circ} 58^{\prime} \mathrm{N}$ and Longitude $8^{0} 33^{\prime} \mathrm{E}$ ). Twenty treatments were replicated four times in completely randomized design (CRD). Sandy-loam top soil was used as planting medium because of its good tilth, good structure and moderate soil moisture. 
The soil was steamed and sterilized manually (by heating the soil in a drum) for 2 hours. The soil was then allowed to cool for 20 minutes before transferring in to jute sac where it was allowed to settle for six weeks. Prior to planting, samples from the sterilized soil were tested for presence of nematodes using Whitehead and Hemming's (1965) method and no live nematode was found.

Preparation and calibration of Inoculum: Eggs of Meloidogyne spp. were extracted from the roots of garden egg (Solanum gilo) that is highly susceptible to root-knot nematodes from farmer's plot (Netscher and Sikora, 1990) using $0.52 \%$ a.i. sodium hypochlorite $(\mathrm{NaOCl})$ method of Hussey and Barker (1973). The plants were lifted gently from farmers' field in the study areas and washed under gentle stream of cool tap water in the laboratory. The roots were chopped in to $1-2 \mathrm{~cm}$ pieces and poured in to 1 liter conical flask containing $0.52 \%$ a.i $\mathrm{NaOCl}$ solution prepared from commercial bleach as follows using the formula of Theodore et al. (2009). The conical flask was corked tightly then manually and vigorously shaken for four minutes to dissolve the gelatinous egg matrices. The suspension now containing free eggs was poured over 200-mesh sieve nested upon 500-mesh sieve. The 500-mesh sieve containing the eggs was rinsed gently under cool gentle stream of tap water to remove the residual bleach. The mesh was thereafter rinsed in to a beaker to collect the eggs. The suspension was adjusted to $150 \mathrm{ml}$ volume and the number of eggs per $\mathrm{ml}$ was estimated with the aid of Doncaster (1962) counting dish under a stereomicroscope.

Inoculation of Cowpea seedlings: At seven days after germination, cowpea seedlings were inoculated with 0 or approximately 5,000 eggs of root-knot nematode (Meloidogyne spp.) by pipetting the eggs in to the holes around the base of the plant and filling the holes with moist soil. Seedlings with 0 inoculations served as control.

Data collection and Analysis: At four, six and eight weeks after inoculation (WAI) data were collected on plant height using measuring tape and stem girth using thread and ruler. Also, data on number of days to $50 \%$ flowering was collected. At maturity, data were also collected on number of pods/plant and number of seeds/pod. The data collected were subjected to analysis of variance (ANOVA) and treatment means were separated using standard error of means (SEM) at $5 \%$ level of probability.

\section{RESULTS}

It was observed that there were significant differences between cowpea lines inoculated with different levels of Meloidogyne spp. eggs (Tables 13). Plant height and stem girth in the uninoculated plants were significantly higher $(p=0.05)$ than the inoculated ones for all the breeding lines except IT84S-2246-4. Plants heights were significantly affected mostly at 6 and 8WAI in the fields at both locations while some breeding lines were only affected at 8WAI.

Table 1 showed that the difference in plant height of IT07K-141 was significant $(p=0.05)$ at 4,6 and 8 WAI. While the differences in plant height of IT06K-
111 and IT06K-116 were statistically significant ( $p=$ 0.05 ) at 6 and 8WAI. However, the differences in plant height of all the cowpea lines were not statistically significant $(p=0.05)$ at 4WAI. The difference in plant height of IT89KD-288, IT07K-2441-1 and IT07K-240-1-4 were statistically significant ( $p$ $=0.05$ ) at 8WAI only, but not significant at 4 and 6WAI. The differences in plant height of other cowpea breeding lines were not statistically significant $(p=$ 0.05 ) throughout the period of the assessment. The differences in stem girth of IT89KD-288 and IT07K141 were statistically significant $(p=0.05)$ at 6 and 8WAI while the stem girth of IT06K-116 and IT07K293-3 were statistically significant $(p=0.05)$ at 8WAI only. At 4WAI, the differences of stem girth of the 10 cowpea breeding lines between inoculated and uninoculated were not statistically significant ( $\mathrm{p}=$ 0.05).

Table 2 shows the effects of Meloidogyne spp. on plant height. At Ringim, the difference in plant height between inoculated and uninoculated cowpea breeding lines in IT89KD-288, IT07K-293-3, IT07K220-1-9 and IT07K-188-4-4-1 were statistically significant ( $p=0.05$ ) between 4, 6 and 8WAI,but only significant between 6 and 8WAI in IT07K-141, IT06K111 and IT06K-116. The table also showed that the differences in plant height in IT07K-240-1-4 and IT07K-244-1-1 were significant $(p=0.05)$ at 8WAI only. The results also showed that the difference in plant height at Minjibir, between inoculated and uninoculated of IT07K-141, IT07K-244-1-1, IT06K111, IT84S-2246-4, IT07K-220-1-9 and IT07K-188-44-1 were significant at 8WAI only. However, the results showed that there was significant difference in plant height in IT07K-240-1-4, IT06K-116 and IT07K293-3 at 6 and 8WAI while IT89KD-288 was found significant at 4, 6 and 8 WAI.

The result in table 3 revealed that the difference in mean stem girth at Minjibir, between inoculated and un-inoculated IT89KD-288, IT07K141and IT07K-2401-4 were statistically significant $(p=0.05)$ from 4 through 8WAI. Also, the difference in stem girth in lines IT07K-188-4-4-1, IT06K-111 and IT06K-116 were found significant $(p=0.05)$ at 6 and 8WAI while IT07K-244-1-1, IT07K-293-3 and IT07K-220-1-9 were significant $(p=0.05)$ only at 8WAI. The difference in stem girth at Ringim as a result of root-knot nematodes were statistically significant $(p=0.05)$ in IT07K-244-1-1 and IT07K-293-3 at 4, 6 and 8WAI but only significant between 6 and 8WAI in IT06K-111, IT06K-116 and IT07K-188-4-4-1 while the differences were significant in IT89KD-288, IT07K-141 and IT07K-240-1-4 at 8WAI. There was no significant difference in stem girth in IT84S-2246-4 and IT07K220-1-9 due to root-knot nematodes inoculation.

Table 4 showed that there was a highly significant difference $(p<0.01)$ between locations and parameters meaning that parameters (plant height, stem girth, days to $50 \%$ flowering, number of seeds/pod and number of pods/plant) have performed differently in the fields and screenhouse. Similar significant differences $(p<0.01)$ were recorded between treatments and parameters (treatments performed differently in relations with parameters) except for seed/pod which was not significant. 
Also, the interaction between locations by treatments with parameters was found to be highly significant ( $p$ $<0.01$ ) except for seed/pod which was significant at $5 \%$ level of probability.

Moreover, days to $50 \%$ flowering were higher in inoculated susceptible cowpea breeding lines in the presence of Meloidogyne spp. as shown in table 5 . The results revealed that there were significant $(\mathrm{p}=$ 0.05) differences between inoculated and uninoculated in number of days to $50 \%$ flowering in all the cowpea lines except IT84S-2246-4, IT07K-2401-4, IT07K-293-3 and IT07K-188-4-4 at Ringim. Days to $50 \%$ flowering were significantly $(p=0.05)$ affected by activities of Meloidogyne spp. in IT89KD288, IT07K-240-1-4, IT06K-111, IT06K-116, IT07K220-1-9 and IT07K-188-4-4 at Minjibir. Also, There were significant $(p=0.05)$ differences in number of days to $50 \%$ flowering in all the cowpea lines screened except IT84S-2246-4, IT07K-240-1-4, IT07K-293-3 and IT07K-188-4-4 in the screenhouse. However, high difference in number of days to $50 \%$ flowering (-6.0) were recorded in IT07K-220-1-9 at Ringim and Minjibir while IT89KD-288 and IT07K-141 had high difference in number of days to $50 \%$ flowering $(-10.0$ and -8.0$)$ respectively in the screenhouse.

Table 1. Effect of Meloidogyne spp. on plant height and stem girth of ten cowpea lines in a screenhouse.

\begin{tabular}{|c|c|c|c|c|c|c|c|}
\hline \multirow{2}{*}{$\begin{array}{l}\text { Cowpea } \\
\text { Lines }\end{array}$} & \multirow{2}{*}{$\begin{array}{l}\text { Inoculum } \\
\text { Level }\end{array}$} & \multicolumn{3}{|c|}{ Mean Plant height $(\mathrm{cm})$} & \multicolumn{3}{|c|}{ Mean Stem girth $(\mathrm{cm})$} \\
\hline & & 4WAI & 6WAI & 8WAI & 4WAI & 6WAI & 8WAI \\
\hline \multirow[t]{3}{*}{ IT89KD-288 } & 0 & 17.0 & 17.7 & 23.4 & 1.5 & 1.7 & 1.9 \\
\hline & 5000 & 16.8 & 17.2 & 18.0 & 1.4 & 1.5 & 1.7 \\
\hline & Diff & 0.2 & 0.5 & $5.4 *$ & 0.1 & $0.2^{*}$ & $0.2 *$ \\
\hline \multirow[t]{3}{*}{ IT07K-141 } & 0 & 19.7 & 27.4 & 31.9 & 1.6 & 1.9 & 2.8 \\
\hline & 5000 & 12.2 & 15.8 & 16.7 & 1.6 & 1.6 & 2.3 \\
\hline & Diff & 7.5* & 11.6* & $15.2 *$ & 0.0 & $0.3^{*}$ & $5.0 *$ \\
\hline \multirow[t]{3}{*}{ IT07K-240 } & 0 & 20.3 & 24.7 & 37.4 & 1.5 & 1.7 & 2.4 \\
\hline & 5000 & 19.3 & 24.9 & 38.4 & 1.5 & 1.8 & 2.6 \\
\hline & Diff & 1.0 & -0.2 & $-1.0 *$ & 0.0 & -0.1 & -0.2 \\
\hline \multirow[t]{3}{*}{ IT07K-244-1-1 } & 0 & 20.9 & 25.7 & 51.7 & 1.6 & 1.8 & 2.2 \\
\hline & 5000 & 21.0 & 27.4 & 56.0 & 1.4 & 1.7 & 2.3 \\
\hline & Diff & -0.1 & -1.5 & $-4.3^{*}$ & 0.1 & 0.1 & 0.1 \\
\hline \multirow[t]{3}{*}{ IT06K-111 } & 0 & 14.5 & 19.0 & 34.4 & 1.3 & 1.6 & 2.0 \\
\hline & 5000 & 16.6 & 24.2 & 51.4 & 1.3 & 1.5 & 2.0 \\
\hline & Diff & -2.1 & $-5.2 *$ & $-17.0^{*}$ & 0.0 & 0.1 & 0.0 \\
\hline \multirow[t]{3}{*}{ IT06K-116 } & 0 & 16.4 & 21.7 & 30.3 & 1.3 & 1.4 & 1.9 \\
\hline & 5000 & 14.6 & 17.1 & 22.8 & 1.3 & 1.3 & 1.4 \\
\hline & Diff & 1.8 & $4.60 *$ & $7.50 *$ & 0.0 & 0.1 & $0.5^{*}$ \\
\hline \multirow[t]{3}{*}{ IT07K-293-3 } & 0 & 19.5 & 24.1 & 36.9 & 1.3 & 1.6 & 1.9 \\
\hline & 5000 & 20.9 & 26.2 & 37.2 & 1.4 & 1.7 & 2.3 \\
\hline & Diff & -1.40 & -1.9 & -0.3 & -0.1 & -0.1 & $-0.4^{*}$ \\
\hline \multirow[t]{3}{*}{ IT84S-2246-4 } & 0 & 17.2 & 22.2 & 36.5 & 1.5 & 1.5 & 2.5 \\
\hline & 5000 & 18.2 & 24.2 & 36.6 & 1.4 & 1.6 & 2.5 \\
\hline & Diff & -1.0 & -2.0 & -0.1 & -0.1 & -0.1 & 0.0 \\
\hline \multirow[t]{3}{*}{ IT07K220-1-9 } & 0 & 19.3 & 24.9 & 41.7 & 1.4 & 1.6 & 2.2 \\
\hline & 5000 & 18.0 & 22.8 & 40.3 & 1.3 & 1.5 & 2.3 \\
\hline & Diff & 1.3 & 2.1 & 0.4 & 0.1 & 0.1 & -0.1 \\
\hline \multirow[t]{3}{*}{ IT07K-188-4- } & 0 & 19.6 & 24.6 & 40.6 & 1.4 & 1.7 & 2.1 \\
\hline & 5000 & 17.4 & 21.0 & 40.3 & 1.4 & 1.6 & 2.1 \\
\hline & Diff & 2.20 & 3.6 & 0.3 & 0.0 & 0.1 & 0.0 \\
\hline $\operatorname{SEM}( \pm)$ & & 2.69 & 4.50 & 0.43 & 0.11 & 0.16 & 0.27 \\
\hline CV $(\%)^{a}$ & & 12.8 & 14.98 & 23.87 & 7.48 & 8.25 & 11.46 \\
\hline
\end{tabular}

Each value is a mean of four replicates.

$\mathrm{SEM}=$ Standard error of means, $\mathrm{CV}=$ coefficient of variation, Diff. = Difference between inoculated and uninoculated WAI $=$ weeks after inoculation, $*=$ significant $(p=0.05)$ 
Table 2. Effect of Meloidogyne spp. on plant height of ten cowpea lines evaluated in the fields.

\begin{tabular}{|c|c|c|c|c|c|c|c|}
\hline \multirow{2}{*}{$\begin{array}{l}\text { Cowpea } \\
\text { Lines }\end{array}$} & \multirow{2}{*}{$\begin{array}{l}\text { Inoculum } \\
\text { Level }\end{array}$} & \multicolumn{3}{|c|}{$\begin{array}{c}\text { Ringim } \\
\text { Mean Plant height (cm) }\end{array}$} & \multicolumn{3}{|c|}{$\begin{array}{c}\text { Minjibir } \\
\text { Mean plant height }(\mathrm{cm})\end{array}$} \\
\hline & & 4WAI & 6WAI & 8WAI & 4WAI & 6WAI & 8WAI \\
\hline \multirow[t]{3}{*}{ IT89KD-288 } & 0 & 16.7 & 18.2 & 22.9 & 8.2 & 8.4 & 8.5 \\
\hline & 5000 & 15.0 & 15 & 13.9 & 7.7 & 7.6 & 7.5 \\
\hline & Diff & $1.7^{*}$ & $3.2 *$ & $9.0 *$ & $0.5^{*}$ & $0.8^{*}$ & $1.0 *$ \\
\hline \multirow[t]{3}{*}{ IT07K-141 } & 0 & 13.8 & 15.5 & 16.9 & 7.8 & 8.0 & 8.3 \\
\hline & 5000 & 14.0 & 14.1 & 13.1 & 7.6 & 7.9 & 7.7 \\
\hline & Diff & -0.2 & $1.4^{*}$ & $3.8^{*}$ & 0.2 & 0.1 & $0.6 *$ \\
\hline \multirow[t]{3}{*}{ IT07K-240 } & 0 & 12.9 & 13.6 & 14.5 & 6.7 & 7.0 & 7.5 \\
\hline & 5000 & 12.8 & 13.1 & 12.4 & 6.5 & 6.4 & 6.4 \\
\hline & Diff & 0.1 & 0.5 & $2.1^{*}$ & 0.2 & $0.6^{*}$ & $0.9 *$ \\
\hline \multirow[t]{3}{*}{ IT07K-244-1-1 } & 0 & 13.8 & 14.5 & 15.6 & 6.5 & 6.9 & 7.5 \\
\hline & 5000 & 14.0 & 13.9 & 13.2 & 6.7 & 6.7 & 6.6 \\
\hline & Diff & -0.2 & 0.6 & $2.4 *$ & 0.2 & 0.2 & $0.9 *$ \\
\hline \multirow[t]{3}{*}{ IT06K-111 } & 0 & 13.6 & 14.8 & 16.3 & 7.4 & 7.6 & 8.1 \\
\hline & 5000 & 12.8 & 13.0 & 12.0 & 7.5 & 7.5 & 7.4 \\
\hline & Diff & 0.8 & $1.8^{*}$ & $4.3^{*}$ & 0.1 & 0.1 & $0.7^{*}$ \\
\hline \multirow[t]{3}{*}{ IT06K-116 } & 0 & 15.6 & 17.0 & 18.1 & 5.5 & 6.1 & 6.8 \\
\hline & 5000 & 14.7 & 14.1 & 13.0 & 5.4 & 5.2 & 5.1 \\
\hline & Diff & 0.9 & $2.9 *$ & $5.1^{*}$ & 0.1 & $0.9 *$ & $1.7^{*}$ \\
\hline \multirow[t]{3}{*}{ IT07K-293-3 } & 0 & 14.4 & 15.0 & 16.1 & 6.2 & 6.7 & 7.5 \\
\hline & 5000 & 13.4 & 13.0 & 12.4 & 6.0 & 6.1 & 5.9 \\
\hline & Diff & $1.0^{*}$ & $2.0^{*}$ & $3.7^{*}$ & 0.2 & $0.6^{*}$ & $1.6^{*}$ \\
\hline \multirow[t]{3}{*}{ IT84S-2246-4 } & 0 & 13.8 & 14.7 & 15.9 & 5.0 & 5.7 & 6.5 \\
\hline & 5000 & 13.3 & 14.5 & 16.5 & 4.8 & 5.3 & 5.9 \\
\hline & Diff & 0.5 & 0.2 & -0.6 & 0.2 & 0.4 & $0.6^{*}$ \\
\hline \multirow[t]{3}{*}{ IT07K220-1-9 } & 0 & 13.5 & 14.2 & 15.4 & 7.8 & 8.0 & 8.3 \\
\hline & 5000 & 12.5 & 12.3 & 12.2 & 7.4 & 7.5 & 7.4 \\
\hline & Diff & $1.0 *$ & $1.9 *$ & $3.2 *$ & 0.4 & 0.5 & $0.9 *$ \\
\hline \multirow[t]{3}{*}{ IT07K-188-4-4- } & 0 & 14.7 & 15.6 & 17.3 & 6.3 & 7.0 & 7.8 \\
\hline & 5000 & 13.4 & 13.2 & 12.9 & 6.3 & 6.5 & 6.3 \\
\hline & Diff & $1.3^{*}$ & $2.4^{*}$ & $4.4^{*}$ & 0.0 & 0.5 & $1.5^{*}$ \\
\hline $\operatorname{SEM}( \pm)$ & & 0.95 & 0.97 & 1.13 & 0.50 & 0.54 & 0.56 \\
\hline$C V(\%)^{a}$ & & 5.98 & 5.96 & 6.54 & 6.69 & 6.93 & 6.99 \\
\hline
\end{tabular}

Each value is a mean of four replicates.

$\mathrm{SEM}=$ Standard error of means $\quad \mathrm{CV}=$ coefficient of variation WAI $=$ weeks after inoculation $*=$ significant $(p$ $=0.05)$ Diff. $=$ Difference in plant height between inoculated and uninoculated. 
BAJOPAS Volume 10 Number 1 June, 2017

Table 3. Effect of Meloidogyne spp. on stem girth of ten cowpea lines in the fields.

\begin{tabular}{|c|c|c|c|c|c|c|c|}
\hline \multirow[t]{2}{*}{ Cowpea lines } & \multirow{2}{*}{$\begin{array}{l}\text { Inoculum } \\
\text { level }\end{array}$} & \multicolumn{3}{|c|}{$\begin{array}{c}\text { Minjibir } \\
\text { Mean stem girth }(\mathrm{cm})\end{array}$} & \multicolumn{3}{|c|}{$\begin{array}{c}\text { Ringim } \\
\text { Mean Stem girth }(\mathbf{c m})\end{array}$} \\
\hline & & 4WAI & 6WAI & 8WAI & 4WAI & 6WAI & 8WAI \\
\hline \multirow[t]{3}{*}{ IT89KD-288 } & 0 & 1.6 & 1.6 & 1.7 & 1.5 & 1.6 & 0.8 \\
\hline & 5000 & 1.6 & 1.6 & 1.4 & 1.3 & 1.4 & 1.2 \\
\hline & Diff & 0.0 & 0.0 & $0.3^{*}$ & $0.2^{*}$ & $0.2^{*}$ & $-0.4^{*}$ \\
\hline \multirow[t]{3}{*}{ IT07K-141 } & 0 & 1.2 & 1.2 & 1.3 & 1.3 & 1.3 & 1.4. \\
\hline & 5000 & 1.1 & 1.1 & 1.0 & 1.1 & 1.1 & 0.9 \\
\hline & Diff & 0.1 & 0.1 & $0.2^{*}$ & $0.2 *$ & $0.2 *$ & $0.5^{*}$ \\
\hline \multirow[t]{3}{*}{ IT07K-240 } & 0 & 1.5 & 1.6 & 1.8 & 1.4 & 1.3 & 1.4 \\
\hline & 5000 & 1.3 & 1.4 & 1.3 & 1.2 & 1.1 & 1.0 \\
\hline & Diff & $0.3^{*}$ & $0.2^{*}$ & $0.5^{*}$ & $0.2^{*}$ & $0.2 *$ & $0.4 *$ \\
\hline \multirow[t]{3}{*}{ IT07K-244-1-1 } & 0 & 1.4 & 1.6 & 1.7 & 1.1 & 1.2 & 1.4 \\
\hline & 5000 & 1.2 & 1.2 & 1.1 & 1.1 & 1.1 & 0.9 \\
\hline & Diff & $0.2^{*}$ & $0.4^{*}$ & $0.6^{*}$ & 0.0 & 0.1 & $0.5^{*}$ \\
\hline \multirow[t]{3}{*}{ IT06K-111 } & 0 & 1.3 & 1.4 & 1.5 & 1.1 & 1.3 & 1.4 \\
\hline & 5000 & 1.2 & 1.2 & 1.1 & 1.0 & 1.1 & 0.9 \\
\hline & Diff & 0.1 & $0.2^{*}$ & $0.4^{*}$ & 0.1 & $0.2^{*}$ & $0.5^{*}$ \\
\hline \multirow[t]{3}{*}{ IT06K-116 } & 0 & 1.0 & 1.2 & 1.4 & 1.0 & 1.2 & 1.4 \\
\hline & 5000 & 1.1 & 1.0 & 0.9 & 1.1 & 0.9 & 0.8 \\
\hline & Diff & 0.1 & $0.2^{*}$ & $0.5^{*}$ & -0.1 & $0.3^{*}$ & $0.5^{*}$ \\
\hline \multirow[t]{3}{*}{ IT07K-293-3 } & 0 & 1.4 & 1.4 & 1.5 & 1.3 & 1.4 & 1.6 \\
\hline & 5000 & 1.2 & 1.1 & 1.0 & 1.3 & 1.3 & 1.2 \\
\hline & Diff & $0.2^{*}$ & $0.3^{*}$ & $0.4 *$ & 0.0 & 0.1 & $0.4^{*}$ \\
\hline \multirow[t]{3}{*}{ IT84S-2246-4 } & 0 & 1.2 & 1.3 & 1.5 & 1.2 & 1.3 & 1.5 \\
\hline & 5000 & 1.2 & 1.4 & 1.6 & 1.2 & 1.4 & 1.6 \\
\hline & Diff & 0.0 & -0.1 & -0.1 & 0.0 & 0.1 & 0.1 \\
\hline \multirow[t]{3}{*}{ IT07K220-1-9 } & 0 & 1.0 & 1.1 & 1.4 & 1.1 & 1.1 & 1.4 \\
\hline & 5000 & 1.0 & 1.0 & 1.3 & 1.0 & 1.0 & 0.9 \\
\hline & Diff & 0.0 & 0.1 & 0.1 & 0.1 & 0.1 & $0.5^{*}$ \\
\hline \multirow[t]{3}{*}{ IT07K-188-4-4 } & 0 & 1.1 & 1.2 & 1.3 & 1.1 & 1.3 & 1.3 \\
\hline & 5000 & 1.0 & 1.0 & 0.9 & 1.0 & 1.0 & 0.9 \\
\hline & Diff & 0.1 & $0.2^{*}$ & $0.4^{*}$ & 0.1 & $0.3 *$ & $0.4^{*}$ \\
\hline $\operatorname{SEM}( \pm)$ & & 0.11 & 0.11 & 0.16 & 0.11 & 0.11 & 0.11 \\
\hline$C V(\%)^{a}$ & & 6.29 & 8.71 & 9.15 & 9.41 & 8.96 & 8.79 \\
\hline
\end{tabular}

Each value is a mean of four replicates.

$\mathrm{SEM}=$ Standard error of means $\quad \mathrm{CV}=$ coefficient of variation WAI $=$ weeks after inoculation $*=$ significant $(p=$ 0.05) Diff. =Difference in stem girth between inoculated and uninoculated. 
BAJOPAS Volume 10 Number 1 June, 2017

Table 4: Mean squares from analyses of variance of effect of Meloidogyne spp. on plant height stem girth, days to $50 \%$ flowering, number of pods per plant, number of seeds per pod and root galls.

\begin{tabular}{|c|c|c|c|c|c|c|c|}
\hline \multirow[b]{2}{*}{ Sources of variation } & \multirow[b]{2}{*}{ Df } & \multicolumn{3}{|c|}{ Parameters } & \multirow[b]{2}{*}{ Pods/plant } & \multirow[b]{2}{*}{ Seeds/pod. } & \multirow[b]{2}{*}{ Galls } \\
\hline & & Plant height & Stem girth & Days to $50 \%$ flw & & & \\
\hline LOC. (L) & 2 & $21323.53 * *$ & $22.90 * *$ & $114.82 * *$ & $2086.08 * *$ & $12.72 \mathrm{NS}$ & $86.72^{* *}$ \\
\hline Loc $\times$ Rep & 9 & 15.7 & 0.40 & 12.05 & 84.31 & 3.81 & 5.71 \\
\hline Treatment $(\mathrm{T})$ & 19 & $103.36 * *$ & $0.49 * *$ & $1006.28^{* *}$ & $744.43 * *$ & $77.31 * *$ & $25.93 * *$ \\
\hline$L \times T$ & 38 & $141.90 * *$ & $0.20 * *$ & $25.79 * *$ & $143.64 * *$ & $3.96 *$ & $3.37 * *$ \\
\hline$L \times T \times R$ & 171 & 28.67 & 0.03 & 3.89 & 23.50 & 2.34 & 0.63 \\
\hline
\end{tabular}

$\mathrm{Df}=$ degree of freedom, Loc $=$ Location, Rep $=$ Replication, Flw = flowering

Ns $=$ not significant,$*=$ significant at 0.05 level of probability and $* *=$ significant at 0.01 level of probability

Table 5 Effect of Meloidogyne spp. infection on mean days to $\mathbf{5 0} \%$ flowering of ten cowpea breeding lines evaluated in a field at Ringim, Minjibir and Screenhouse.

Cowpea Inoculum

\begin{tabular}{|c|c|c|c|c|}
\hline $\begin{array}{l}\text { Cowpea } \\
\text { Lines }\end{array}$ & $\begin{array}{l}\text { Inoculum } \\
\text { Level }\end{array}$ & Ringim & Minjibir & Screenhouse \\
\hline \multirow[t]{3}{*}{ IT89KD-288 } & 0 & 65 & 65 & 49 \\
\hline & 5000 & 69 & 68 & 59 \\
\hline & Diff & $-4.0 *$ & $-3.0 *$ & $-10 *$ \\
\hline \multirow{3}{*}{ IT07K-141 } & 0 & 73 & 73 & 63 \\
\hline & 5000 & 75 & 75 & 71 \\
\hline & Diff & -2.0 & -2.0 & $-8.0 *$ \\
\hline \multirow[t]{3}{*}{ IT07K-240 } & 0 & 53 & 53 & 53 \\
\hline & 5000 & 56 & 57 & 55 \\
\hline & Diff & $-3.0 *$ & $-4.0 *$ & -2.0 \\
\hline \multirow[t]{3}{*}{ IT07K-244-1-1 } & 0 & 52 & 52 & 52 \\
\hline & 5000 & 53 & 53 & 53 \\
\hline & Diff & -1.0 & -1.0 & $-1.0^{*}$ \\
\hline \multirow[t]{3}{*}{ IT06K-111 } & 0 & 41 & 41 & 41 \\
\hline & 5000 & 46 & 45 & 45 \\
\hline & Diff & $-5.0 *$ & $-4.0 *$ & $-4.0 *$ \\
\hline \multirow[t]{3}{*}{ IT06K-116 } & 0 & 47 & 47 & 47 \\
\hline & 5000 & 50 & 50 & 50 \\
\hline & Diff & $-3.0 *$ & $-3.0 *$ & $-3.0 *$ \\
\hline \multirow[t]{3}{*}{ IT07K-293-3 } & 0 & 42 & 42 & 42 \\
\hline & 5000 & 44 & 44 & 44 \\
\hline & Diff & -2.0 & -2.0 & -2.0 \\
\hline \multirow[t]{3}{*}{ IT84S-2246-4 } & 0 & 47 & 47 & 48 \\
\hline & 5000 & 47 & 47 & 47 \\
\hline & Diff & 0.0 & 0.0 & 1,0 \\
\hline \multirow[t]{3}{*}{ IT07K220-1-9 } & 0 & 50 & 50 & 50 \\
\hline & 5000 & 56 & 56 & 55 \\
\hline & Diff & $-6.0 *$ & $-6.0 *$ & $-5.0 *$ \\
\hline \multirow[t]{3}{*}{ IT07K-188-4-4- } & 0 & 43 & 43 & 43 \\
\hline & 5000 & 46 & 46 & 45 \\
\hline & Diff & $-3.0 *$ & $-3,0 *$ & -2.0 \\
\hline $\operatorname{SEM}( \pm)$ & & 2.07 & 2.07 & 2.50 \\
\hline CV $(\%)^{\mathrm{a}}$ & & 3.47 & 3.47 & 4.36 \\
\hline
\end{tabular}

Each value is a mean of four replicates.

$\mathrm{SEM}=$ Standard error of means, $\mathrm{CV}=$ coefficient of variation $*=$ significant $(\mathrm{P}=0.05)$ Diff. $=$ Difference between inoculated and uninoculated. 


\section{DISCUSSION}

Meloidogyne spp. reproduced in all the cowpea line evaluated except IT84S-2246-4 and successfully induced root galls and egg masses on roots of susceptible cowpea plants. The resistance response of IT84-2246-4 to Meloidogyne spp, in all the experiments showed an increase in growth parameters than the susceptible breeding lines. Plant height and stem girth were significantly affected by Meloidogyne spp. as indicated by control (uninoculated) plants. This suggests that eggs inoculum was viable. The uninoculated (control) plants gave significantly better vegetative growth than their inoculated counterparts.

For all the cowpea breeding lines inoculated with eggs of Meloidogyne spp, there was a decrease in plant height and stem girth. Inoculum led to reductions in growth parameters. Cowpea plants inoculated with Meloidogyne spp. showed a decrease in growth parameters than the uninoculated. This was most likely due to damage caused by the increasing number of nematodes that invaded plant roots, probably causing reduced nutrient and water uptake (Karssen and Moens, 2006).The decreasing agronomic parameters (plant height and stem girth) recorded for the susceptible cowpea was probably a result of stunting action of the root-knot nematodes. This is conformity with finding of Ezigbo (1973) reported that Meloidogyne spp. induced stunting which results in poor growth and in severe cases premature death in cowpea, a decline in quality and yield of the crop and reduced resistance to other stresses. Moreover, according to (Hussey, 1989), an increase in stem diameter was due to the uptake and transportation of water and nutrients which are dependent on the health of the roots. Gommers et al. (1991) also reported that increase in stem diameter was due to the translocation of water and nutrients to the shoots. The uninoculated (control) plants gave significantly better vegetative growth than their inoculated counterparts. According to (Eisenbacket al.1991), heavily diseased plants do not respond to water, this is because the nematodes have severely damaged the conducting tissues of the plant at the roots. As a consequence, stem diameter and top growth is reduced. The reduction in stem girth can cause a significant yield loss which is similar to the finding of (Robert, 1987 and Sikora and Fernandez, 1990) reported that flow of water and nutrients in to the plants is greatly influenced due to reduction in stem girth. Powell, (1971); Anwar and Din, (1986); and Khan et al., (2000) reported that in addition to

\section{REFERRENCES}

Anon., 1961.Report of the Department of Agricultural Research for the year 1959/1960. Federal Printing Division, Lagos-Nigeria.

Anwar, S.A. and Din, G.M., 1986. Nematodes: Biotic constrains to plant health. Parasitology, 3: 48-53.

Anwar S.A. and Van Gundy, S.D., 1993. Effect of Meloidogyne incognita on root and shoot nematode infestation reduction in stem girth causes disturbance in nutrients up take and leads to nutrient deficiency.

The control (uninoculated) plants started flowering earlier than the inoculated. Early flowering is very important because it affects the time of maturity and harvesting of plants. The number of days for $50 \%$ to flower when compared between inoculated and uninoculated shows that Shorter generation time suggests more susceptibility while longer generation time which translated to low gall index is a reflection of low root-knot nematode infection and damage as recorded in IT84S-2246-4.This therefore accounts for its enhanced root development and ability to tap nutrient from the soil to carry out normal physiological functions.

\section{CONCLUSION}

This result shows that Meloidogyne spp. induced stunting which results in poor growth and in severe cases affects the time of maturity and harvesting of cowpea in all the ten cowpea breeding lines except IT84S-2246-4.

Recommendations: It is therefore recommended that (i) soils be screened for the presence / level of root-knot nematode, prior to planting of cowpea (ii) highly nematode infested soil be treated before sowing in order to ensure high qualitative harvest.

Contribution of Authors: This research article is part of the first author's Master's Degree Dissertation. $\mathrm{He}$, therefore, carried out the field layout of the experimental design, sterilized the soil for screenhouse experiment, sowing of seeds, management of plots, nematode assay, data collection at both fields and screenhouse, data analyses and report writing. The second author supervised the research activities from planning to completion. He guided preparation of the manuscript and edited the report.

Conflict of Interest: There was no conflict of interest among the authors with regards to this publication.

\section{Acknowledgements}

The authors are grateful to the management and staff of International Institute of Tropical Agriculture (IITA), Kano station for graciously providing the cowpea breeding lines, screenhouse, screening plot for this experiment and other technical support.

growth parameters of susceptible and resistant varieties of tomato. Afro-Asian $\mathrm{J}$. Nematol., 3: 152-160.

Babatola, J. O. and Omotade, O. 1991. Chemical control of the nematode pests of cowpea, Vigna unguiculata (L.)Walp. Crop Protection 10: 131-134. 
Davis, R.F., Earl, H.J. and Timper, P., 2003. Interaction of root-knot nematode stress and water stress in cotton.University of Georgia cotton research and extension report, pp. 312-315.

Doncaster, C. C. 1962. A counting dish for nematodes. Nematologica 7:334-336.

Eisenback, J. D., Carmel-Goren, L., Hareven, D, and Triantaphyllou, H. H.1991. Root knot nematodes: Meloidogyne spp. and races. In: Manual of Agricultural Nematology. Nickle, W. R. and Marsel Dekker,Inc. New York, USA.

Ezigbo, J. C. 1973. Aspects of the host-parasite relationships of root-knot nematodes (Meloidogyne spp.) on cowpeas. M.Sc. thesis (Unpublished). Imperial College of Science and Technology, Berkshire, London. $250 \mathrm{pp}$.

FAOSTAT, 2014.http://faostat.fao.org/site-Food and Agricultural Organization of the United Nations. Rome, Italy.accessed on $24^{\text {th }}$ August,2016.

Gommers, F. J., Janssen, R., and Bakker. J. 1991. Mendelian proof for a gene- for-gene for relationship between virulence of Globodera rostochiensis and the high resistance gene of Solanum tuberosum spp. andigena срс 1673, Revue de Nematoloie 14, 213 219pp.

Hussey, R.S. 1989. Disease inducing secretions of plant parasitic nematodes. Annual Review of Phytopathology. 27:123-141.

Khan, H. U., Ahmed, W. And Khan, M. A. 2000. Evaluation of resistance of fifteen tomato cultivars against root-knot nematode (Meloidogyne incognita), Pakistan Journal of Phytopathology, 12: 50 -52.

Karssen, G. and Moens, M. 2006. Root-knot nematodes. pp. 59-90. In: Perry, R.N. andMoens, M. (Eds). Plant Nematology. CABI publishing.

Mishra, S. D. 1992. Nematode pests of pulse crops In: Nematodes pests of Vegetable crops, D. S. Bhatti and

R.K.Walia, (eds.) CBS Publishers and Distributors, Delhi India. 140pp.

Netscher, C. and Sikora, R.A. 1990. Nematode parasites of vegetables. Pages: 237-283. In: Plant Parasitic Nematodes in Subtropical and Tropical Agriculture. Luc, M.; Sikora, R.A. and Bridge (eds.). CAB International.
Olowe, T. (2009). Cowpea Germplasm Resistant toMeloidogyne arenaria Race 1, Meloidogyne incognita Race 4 and Meloidogyne javanica. European Journal of Scientific Research, 28(3), 338-350.

Powell, N. T. 1971. Interaction between nematode and fungi in disease complex. Annual review, phytopathology 9: 253 - 274.

Quin, F. M. 1997. Importance of cowpea. Pp. Ix-xii In: Advances in cowpea research Co-publication of IITA and JIRCAS IITA, Ibadan Nigeria. Proceeding of the $2^{\text {nd }}$ Cowpea Research Conference held in Accra, Ghana 3-7 september, 1995, p190-196.

Roberts P. A. 1987. The influence of planting date of carrot and Meloidogyne incognitareproduction and injury to roots. Nematologica 33: 335 - 342pp.

Sasser, J. N. 1980. Root-knot nematodes: a global menace to agriculture. Plant Disease 64:3641.

Sikora, R. A. and Fernandez, E. 1990. Nematodes parasites of vegetables. pp319 - 392 In: Plant parasitic nematodes in Subtropical and Tropical Agriculture. Luc, M. Sikora, R. A. and Bridge, J. (eds.) 1st edition, Wallingford, UK, CABI Bioscience Publication. 917pp

Singh, B. B., Ehlers, J. D. Sharma, B. And Freirefilho, F. R. 2003. Recent progress in cowpea breeding. Pp. 22-40 In:Challenges and opportunities for enhancing sustainable cowpea production. Proceedings of the World Cowpea Conference III held at IITA Ibadan, Nigeria. 4-8 September, 2002.

Tarawali, S.A., Singh, B.B., Peters, M. and Blade, S.F. 1997. Cowpea haulms as fodder. pp 313-325 In: Singh, B. B., Mohan Raj D. R, Dashiell, K. $\mathrm{E}$, Jackai LEN (eds.) Advances in Cowpea Research. Co publication of International Institute of Tropical Agriculture(IITA) and Japan International Research Centre for Agricultural Sciences (JIRCAS). Sayce, Devon, UK..

Theodore, L. B., Lemay,H. J., Bursten, B. E. and Morphy, C. J. 2009. Chemistry the Central Science. Eleventh edition, Pearson Education Limited, London. 144pp.

Whitehead, A. G. and Hemming, J.R. 1965. A comparison of some quantitative methods of extracting small vermiform nematodes from soil. Annals of Applied Biology 55:25-38. 